\title{
碟で構成された河床における物質輸送に関する実験的研究 \\ EXPERIMENTAL STUDY ON MASS TRANSFER IN POROUS RIVERBED
}

\author{
長 岡 裕* ·大垣眞一郎** \\ By Hiroshi NAGAOKA and Shinichiro OHGAKI
}

\begin{abstract}
Mass transfer mechanism in porous riverbed was investigated using chloride tracer method and a hotfilm anemometer in two experimental open channels which have porous media composed of $1.9 \mathrm{~cm}$ and $4.08 \mathrm{~cm}$ diameter ceramic ball respectively. Water depth to particle diameter ratio was about 1.7 and surface flow mean velocity was $3.9 \mathrm{~cm} / \mathrm{s}-42$ $\mathrm{cm} / \mathrm{s}$.

Flow over porous riverbed was found to have very high turbulent intensity near porous boundary, which was about $20 \%$ of surface flow mean velocity in all hydraulic conditions. Values of vertical-direction diffusion coefficient in porous media increased with increasing surface flow mean velocity, and were found to have the distribution pattern in porous media which shows linear decrease with depth. Observed values of diffusion coefficient near porous boundary satisfied the theoretical relationship between diffusion coefficient and turbulent intensity.
\end{abstract}

Keywords : mass transfer, porous riverbed, diffusion, turbulent flow, self-purification

\section{1.はじめに}

河川の水質污濁を解決する 1 つの有力な方法として, 河川が本来もっている自鿇作用を利用する手法が近年注 目を浴びている. 喽の表面に付着した微生物膜によって 河川水中の有機物を分解し净化を促進させる砅間接触酸 化法の試み等 ${ }^{1}$ がその一例である. また, 河川空間の親 水機能が強調されるようになり, 特に都市域においては 人工河川等のせせらぎ空間の設計, 建設も進められてお り, 東京都の玉川上水, 野火止用水では下水処理水を導 入することによって「清流の復活」事業が行われた ${ }^{21}$. 以上の現況をみると河川の自净作用を最大限に活用でき るような河道の設計法を確立することが望まれている.

河床が砅等で構成されている場合, 単なる平板の河床 に比べ自浄にかかわる生物の付着面積が増加し, 自净作 用を大きくさせることができる3 と考えられる.しかし そのメカ二ズムを定量的に明らかにするには碩層におけ る水理学的特性, 特に深さ方向の物質輸送のメカニズム を解明し, 基質 (有機物等) や溶存酸素の砂層深部への 供給能力を評価する必要がある. また, 河床の凹凸がも

\footnotetext{
* 正会員 工博 東京大学助手 工学部都市工学科

** 正会員 工博 東京大学助教授 工学部都市工学科 ( T113 文京区本郷 7-3-1)
}

たらす水面付近の乱流が溶存酸素の再曝気を促進する効 果, 河床付近の大きな乱れが水中の浮遊物質の沈降, 底 泥の巻き上げ等に与える影響, 表層部が好気的に保たれ 深部が嫌気的になることによる硝化, 脱窒の同時進行 ${ }^{4)}$ 等の現象に対しても河川の自净作用を考えるうえでは考 慮が必要である.

一方，公園等において親水空間を形成する人工水路等 は一般に非常に浅い流れとなっており，たとえば万博記 念公園上津水路においては水深 $2 \mathrm{~cm}$, 流速 $33 \mathrm{~cm} / \mathrm{s}$, 同下津水路では水深 $7 \mathrm{~cm}$, 流速 $40 \mathrm{~cm} / \mathrm{s}$ となっている5 . このような水路において路床に砂等を積み重ねた場合, 水深と粒径のスケールがほぼ等しくなるという, 通常の 河川の場合と異なるかなり特殊な条件となる.

本研究は, 水深と粒径のスケールが同程度になるよう な碩層を有する実験水路において, 碩層内の物質輸送機 構の解明を試みたものである.

\section{2. 実験装置および実験方法}

\section{（1）実験水路}

実験にはFig. 1 に示すような透明の塩化ビニール製の 大小 2 種類の開水路を用いた. 大水路は長さ $3 \mathrm{~m}$, 幅 $18 \mathrm{~cm}$, 小水路は長さ $2 \mathrm{~m} 25 \mathrm{~cm}$, 幅 $18 \mathrm{~cm}$ で, それぞ れ粒径 $4.08 \mathrm{~cm}$, および $1.9 \mathrm{~cm}$ の磁製球を最密充填に 
7 層積み重ねた硆層を有している. なお, 粒径は平均値 である. 鿬層の厚さは大水路で $23.6 \mathrm{~cm}$, 小水路で $11.5 \mathrm{~cm}$ となっており，空隙率はそれぞれ $36.2 \%, 32$ \%であった．実験はTable 1 に示す 12 種類の水理条件 について行った. Case 1〜Case 9 が大水路, Case 10〜 Case 12 が小水路についての実験であり，粒径に対する 水深の比を約 1.7 と統一した. 水路は水平に保たれてい る.

\section{（2）拡散係数の測定}

導電率の測定には 4 電極法を利用した導電率計 (KENEK 社製) を用いた。センサーはFig. 2 に示す ような大小 2 種類のものをビニール銅線を用いて自作し たものである. 大小それぞれの水路に 5 個のセンサーを 碩層の表面，1層目，2層目， $\cdots, 4$ 層目に埋め込み

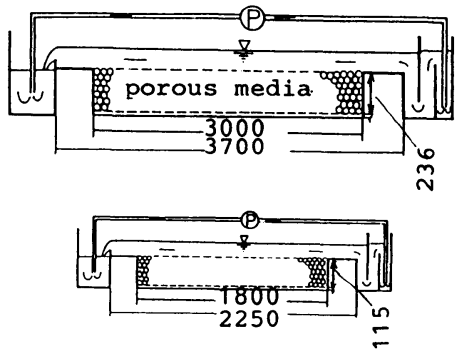

Fig. 1 Experimental open channels. (unit : mm)

Table 1 Experimental conditions.

\begin{tabular}{|c|c|c|c|c|}
\hline & $\begin{array}{l}\text { particle } \\
\text { diameter } \\
(\mathrm{cm})\end{array}$ & $\begin{array}{l}\text { * mean } \\
\text { velocity } \\
(\mathrm{cm} / \mathrm{s})\end{array}$ & $\begin{array}{l}\text { friction } \\
\text { velocity } \\
(\mathrm{cm} / \mathrm{s})\end{array}$ & $\begin{array}{l}\text { depth } \\
(\mathrm{cm})\end{array}$ \\
\hline $\begin{array}{ll}\text { case } & 1 \\
\text { case } & 2 \\
\text { case } & 3 \\
\text { case } & 4 \\
\text { case } & 5 \\
\text { case } & 6 \\
\text { case } & 7 \\
\text { case } 8 \\
\text { case } 9 \\
\end{array}$ & $\begin{array}{l}4.08 \\
4.08 \\
4.08 \\
4.08 \\
4.08 \\
4.08 \\
4.08 \\
4.08 \\
4.08 \\
\end{array}$ & $\begin{array}{l}42.8 \\
28.0 \\
21.1 \\
16.7 \\
11.7 \\
8.9 \\
5.8 \\
5.5 \\
3.9 \\
\end{array}$ & $\begin{array}{l}4.30 \\
4.07 \\
2.70 \\
2.18 \\
1.53 \\
1.15 \\
\\
\end{array}$ & $\begin{array}{l}6.75 \\
6.75 \\
6.75 \\
6.75 \\
7.00 \\
6.75 \\
6.75 \\
6.75 \\
6.75 \\
\end{array}$ \\
\hline $\begin{array}{ll}\text { case } & 10 \\
\text { case } 11 \\
\text { case } 12\end{array}$ & $\begin{array}{l}1.9 \\
1.9 \\
1.9\end{array}$ & $\begin{array}{l}30 . \overline{2} \\
20.3 \\
11.2\end{array}$ & $\begin{array}{l}2.91 \\
1.65 \\
1.09\end{array}$ & $\begin{array}{l}3.2 \\
3.2 \\
3.2\end{array}$ \\
\hline
\end{tabular}

* : calculated from integral of velocity profile

- : could not be measured due to very small value of water surface slope

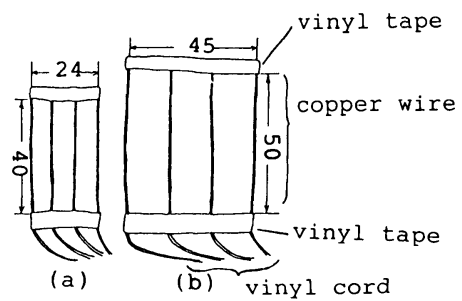

Fig. 2 Sensor for conductivity measuring in porous media.

(a) - - case 1-case 9

(b) - - case 10-case 12 (unit : mm)
(Fig. 3 参照)，前述の導電率計に接続した。また， Fig. 3 中に示すように，センサー 0 とセンサー 1 で挟ま れた領域における平均的な深さ方向拡散係数を $K_{1}$, セ ンサー 1 とセンサー 2 の間の領域の拡散係数を $K_{2}$ と し，同様に $K_{3}, K_{4}$ を定義する。

水路の表流水を循環させながら塩水を下流側受水槽に 瞬間的に投入し，鿬層表面の導電率変化（センサー0 の 出力) および喽層各深さにおける導電率の応答（セン サー1〜センサー 4 の出力）を測定した。導電率計から の 5 系列の出力電圧は $\mathrm{AD}$ 変換の後にパーソナルコン ピューター（日本電気社製 PC 8801）を通してフロッ ピーディスクに収納し, その後同 PC 9801 を用いて解 析を行った。実験における導電率の範囲はおよそ 200 $\mu \mathrm{s} / \mathrm{cm} \sim 600 \mu \mathrm{s} / \mathrm{cm}$ 程度 $(\mathrm{NaCl}$ 濃度 0〜200 ppm) であ り, 密度流の影響は排除できると考えられ, 導電率と塩 分濃度の線形性は確認した。 また, 濃度と導電率の出力 電圧の較正は毎実験ごとに行った。

本実験の場合, 粒径に対するセンサーのスケールが比 較的小さく, センサーの埋め込み位置によって測定值に 誤差が生じることが予想されるので, センサーの埋め込 み位置を少しずつずらしながら同様の実験を 5〜10 回程 度繰り返し，各センサーよりの出力を平均化したものを 計算した。結果の一部を Fig. 4, Fig. 5 に示す。 $c_{0}, c_{1}$, $c_{2}, c_{3}, c_{4}$ はそれぞれセンサー0一七ンサー4の出力を 表わしている. 縦軸の無次元導電率とは $c_{0}$ のピーク時 の値で基準化した導電率である. 両図から, 砅層内各層 の導電率が水路水の循環に伴う砅層表面の導電率変化に 対し， 1 層目， 2 層目， $\cdots, 4$ 層目の順で次々と追従す るように変化していることがわかる.

\section{(3) 拡散係数の計算方法}

磷層各深さにおける深さ方向拡散係数 $\left(K_{1}, K_{2}, K_{3}\right.$ お よび $\left.K_{4}\right)$ の計算は以下の手順で行う.

喽層内の深さ方向物質輸送現象を一次元フィック型拡

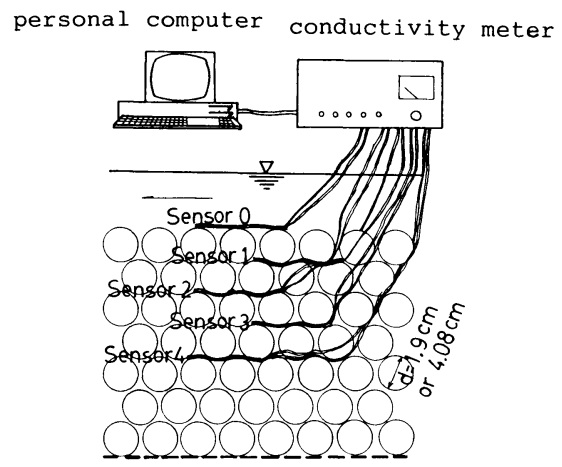

Fig. 3 Setting of conductivity sensors in porous media and definition of diffusion coefficient $K_{1}, K_{2}, K_{3}$, and $K_{4}$. 


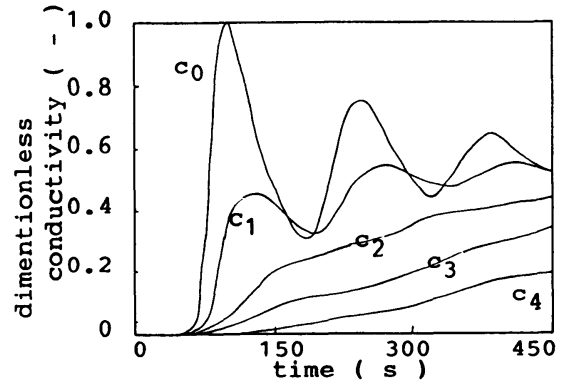

Fig. 4 Conductivity variation in porous media (case 7 ).

$c_{0} \cdots$ surface

$c_{1} \cdots 1$ st layer from surface

$c_{2} \cdots 2$ nd layer from surface

$c_{3} \cdots 3$ rd layer from surface

$c_{4} \cdots 4$ th layer from surface

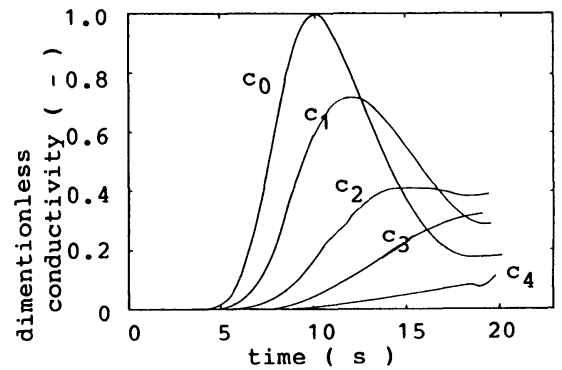

Fig. 5 Conductivity variation in porous media (case 10).

$c_{0} \cdots$ surface

$c_{1} \cdots 1$ st layer from surface

$c_{2} \cdots 2$ nd layer from surface

$c_{3} \cdots 3$ rd layer from surface

$c_{1} \cdots 4$ th layer from surface

散方程式

$$
\begin{aligned}
& \frac{\partial c(t, z)}{\partial t}=K \frac{\partial^{2} c(t, z)}{\partial z^{2}} \\
& c(t, z) \text { : 濃度, } z \text { : 距離（深さ） } \\
& t \text { : 時間, } K \text { : 拡散係数 }
\end{aligned}
$$

で表わされるとする．ただしここでいう拡散係数とは鉛 直方向の拡散と，球を迂回する流れの移流による物質輸 送 (分散) の両方を含めた包括的な見掛けの抎散係数で

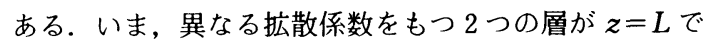
接し, 上層側の拡散係数が $K_{\mathrm{I}}$, 下層側が $K_{\mathbb{I}}$ で与えられ, 2 層の境界面 $(z=L)$ より $L$ だけ上方の $z=0$ におけ る濃度変化が $f(t)$ で与えられる場合を考える．境界条 件は,

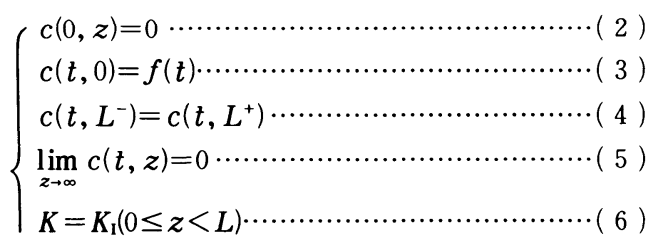

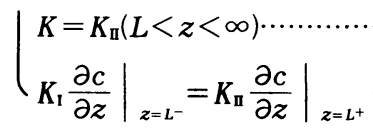

となり,この境界条件の下で式（1）を解くと 2 層の境 界面における濃度変化

$$
\begin{aligned}
c(t, L)= & \frac{L}{(a+1) \sqrt{\pi K_{\mathrm{I}}}} \int_{0}^{t} \frac{f(\tau)}{(t-\tau)^{3 / 2}} \\
& \cdot \sum_{n=0}^{\infty} b^{n}(2 n+1) \exp \left\{-\frac{(2 n+1)^{2} L^{2}}{4 K_{\mathrm{I}}(t-\tau)}\right\} d \tau
\end{aligned}
$$

ここに, $\left(a=\sqrt{\frac{K_{\mathrm{II}}}{K_{\mathrm{I}}}}, \quad b=\frac{a-1}{a+1}\right)$

を得る. 式 $(9)$ 中の $L$ を磁層中に埋め込んだ 5 組の センサーの互いの垂直方向の距離と考えれば，この式に よって，あるセンサーの出力 $f(\tau)$ が与えられたとき, それより Lだけ深い位置のセンサー出力が示されるこ とになる．たとえば $f(\tau)$ としてセンサー0の出力を考 え， $K_{1}$ として $K_{1}$ (センサー0 とセンサー 1 に挟まれた 層の拡散係数)， $K_{\mathrm{I}}$ として $K_{2}$ (センサー 1 の下層の拡 散係数）を考えれば，式（9）の左辺はセンサー1の出 力を示すことになる (Fig. 3 参照)。そこで実験で得た センサー0の出カカーブ (実測値) および $K_{2}$ として適 当な値を与えれば, 式（9）で得られる曲線とセンサー 1 の実測曲線をフィットするようにして最適の $K_{1}$ を一 義的に定めることができる．この場合に与えるべき $K_{2}$ の值はセンサー 1 とセンサー 2 の出力を用いた同様の フィッティングによって $K_{3}$ の值から定められ, さらに $K_{3}$ の值はセンサー 2 とセンサー 3 の出力のフィッティ ングから $K$ 、の値を与えることによって求められる. セ ンサー 3 より下方の搪散係数 $K_{4}$ は, 式 $(9)$ で $K_{1} \rightarrow$ $K_{\text {II }}$ の極限をとり，

$$
c(t, L)=\frac{L}{2 \sqrt{\pi K_{\mathrm{I}}}} \int_{0}^{t} \frac{f(\tau)}{(t-\tau)^{3 / 2}} \exp \left\{-\frac{L^{2}}{4 K_{\mathrm{I}}(t-\tau)}\right\} d \tau
$$

を得てから，七ンサー 3 とセンサー 4 の出力のフィッ ティング操作によって同様に定められる.

以上 4 回のフィッティング操作によって礫層中の拡散 係数 $K_{1}, K_{2}, K_{3}$ および $K_{4}$ を決定することができる．な お，計算値と実測值とのフィッティングにおいては実際 の境界条件と上記式 (2) 〜式 (8) の理論解の境界条 件（無限まで層が続いているとした点に関し）との相違 を考慮し, 導電率の立ち上がり時についてのデータのみ を用いた。

\section{（4）流速および乱れ強度の測定}

平均流速の測定には KENEK 社製プロペラ式流速計 （プロペラ直径 $5 \mathrm{~mm}$ ) を用いた。乱流計測には KANOMAX 社製ホットフィルム流速計を用い，プローブ はコニカル型 $(1231 \mathrm{~W})$ を使用した。データ処理は導電 


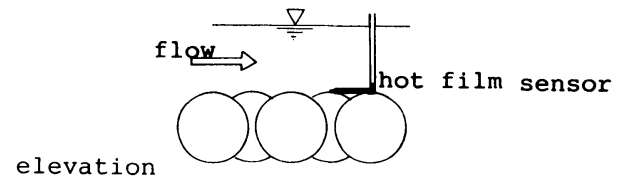

elevation

plan

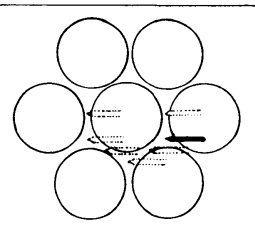

Fig. 6 Position of hot film sensor for measuring turbulent flow at porous boundary.

率の場合と同様に, $\mathrm{AD}$ 変換後にパーソナルコンピュー タ一内で行った．礫層表面の境界面における乱流計測に おいては Fig. 6 に示すように球の周囲の同一平面上 7 か 所において測定した．測定結果は幾何学的な形状を考慮 して重みをつけ平均化した。

\section{3. 実験 結果}

\section{（1）磞層上の表面流の流速分布と乱れ強度分布}

Fig. 7 に喽層上の流れの流速分布および乱れ強度（乱 れの平方根 2 乗平均）の分布の一例（Case 2 ）を示す. 比較のため同図上には同流量同水深の条件下での同じ水 路を滑面にした場合（磁製球層の上を塩化ビニール板で 覆った）の流れについての結果もプロットしてある．乱 れ強度の測定の原デー夕数は 6300 , サンプリング周期 は 0.002 秒である．流速分布を水深方向に積分した単位 幅当たり流量が滑面と磞層とで異なっているが，これは 礫層内を流れる浸透流の影響, 乱れ強度が非常に大きい 系におけるプロペラ流速計の信頼性の問題等が原因と考 えられる. 乱れ強度分布をみると喽層上の流れにおいて は非常に大きな乱れが発生し，それが流れの表面付近に

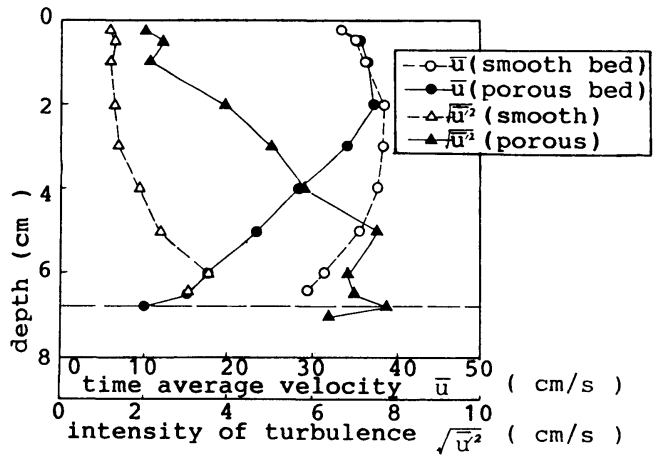

Fig. 7 Distribution of time average velocity $(\bar{u})$ and intensity of turbulence $\left(\sqrt{u^{\prime 2}}\right)$ in flow over porous bed and smooth bed (Case 2).
まで及んでいる様子がうかがえ，路床を磼層に変えるこ とによって流れ全体の様子は大きく変貌し，非常に大き な乱れの支配する系が生じることがわかる.

\section{（2）拡散係数の計算結果}

梁さ方向拡散係数 $K_{1}, K_{2}, K_{3}, K_{4}$ と各水理条件におけ る表流水平均流速との関係を両対数で表わしたものが， Fig. 8 (大粒径, Case 1 Case 9) および Fig. 9 (小粒径, Case 10〜Case 12) である.また Fig. 10, Fig. 11 は $K_{1}$ で基準化した碟層内の拡散係数分布をそれぞれ大粒径， 小粒径の場合に分けてプロットしたものである。これら の図より，本実験の水理条件の範囲においては各層の拡 散係数は表面流の平均流速の増加に応じて大きくなるこ と，礫層内においては拡散係数の值は深くなるにつれて ほぼ直線的に減少し，碩層表面から 3 4 層目において は 0 1 層目の約 10～50％の範囲の值を示すことがわ かった。

\section{（3）磷層境界面における乱れ}

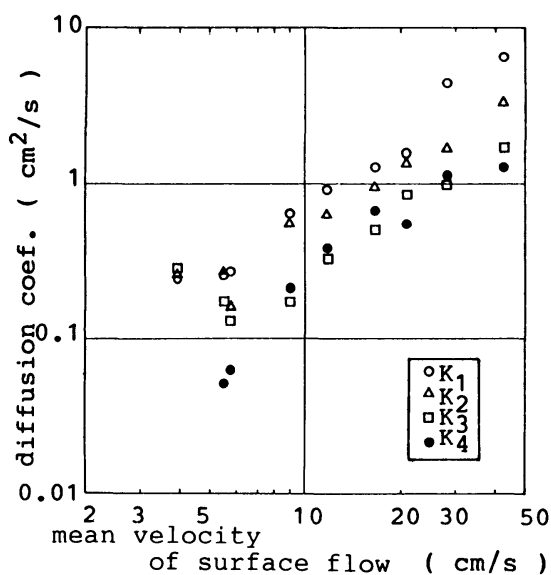

Fig. 8 Relationship between diffusion coefficient in porous media and mean velocity of surface flow $(d=4.08 \mathrm{~cm})$.

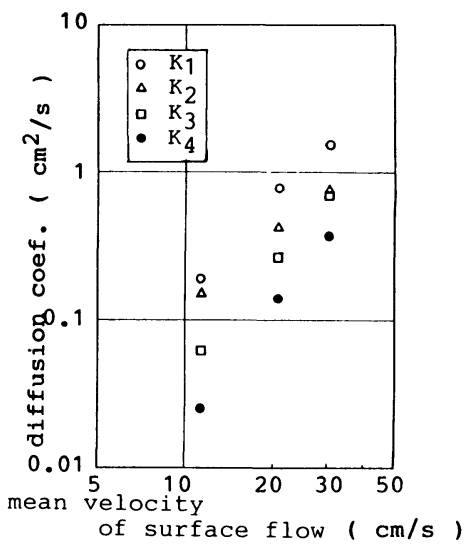

Fig. 9 Relationship between diffusion coefficient in porous media and mean velocity of surface flow $(d=1.9 \mathrm{~cm})$. 


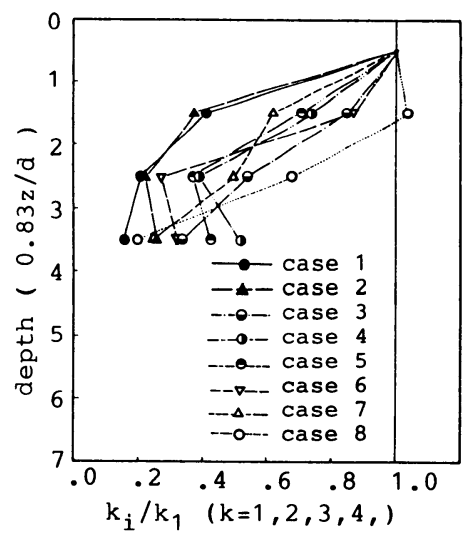

Fig. 10 Distribution of diffusion coefficient (ratio of diffusion coef. in each layer to $\left.K_{1}\right)$ in porous media ( $d=$ $4.08 \mathrm{~cm})$.

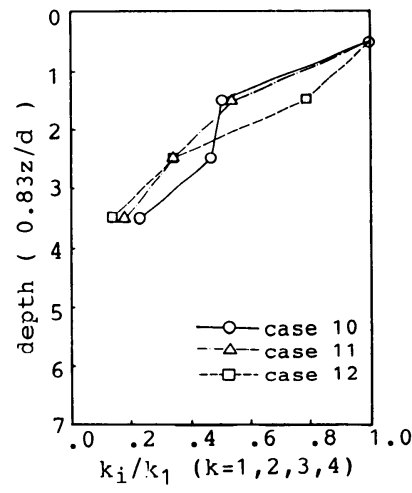

Fig. 11 Distribution of diffusion coefficient (ratio of diffusion coefficient in each depth to $\left.K_{1}\right)$ in porous media $(d=$ $1.9 \mathrm{~cm})$.

Fig. 12 に磂層境界面における乱流データの一例（大 粒径, Case 2) を示す。これより流速変動に周期性があ ることがうかがえ，磷層境界面においては大きなスケー ルの渦が支配的であることが予想される．境界面付近に ウォーターブルー粒子を落として流れを可視化した結 果, 球の周囲を回り込んで下方に潜り込む流れや，逆に 下方から涌き上がる流れを観察しており，磷層境界面に おける粒径程度の大きさをもった渦の存在がうかがえ る. Fig. 13 は磁層境界面における乱れ強度と表面流平 均流速との関係をプロットしたものである.この結果よ り通常の䃯のスケール（直径 $2 \sim 5 \mathrm{~cm}$ 程度）を有する 喽層上の流れにおいては，表面流平均流速のほぼ $20 \%$ 程度の乱れ強度が磷層境界において発生していることが わかる.

\section{4. 考察}

（1）磷首境界面付近における深さ方向拡散係数の機

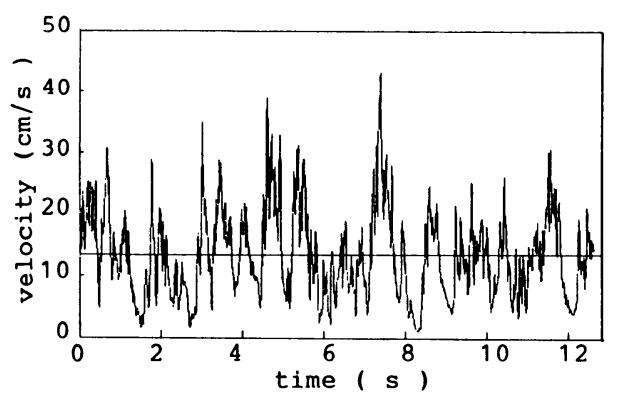

Fig. 12 Example of turbulent flow data at porous boundary (Case 2).

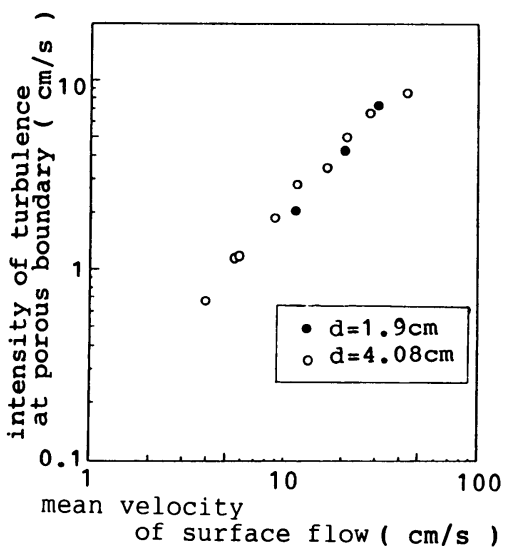

Fig. 13 Relationship between intensity of turbulence at porous boundary and mean velocity of surface flow.

\section{棈}

磷層内における深さ方向拡散係数 $K$ は,

$$
K=I_{0} \sqrt{\overline{u_{z}^{\prime 2}}}
$$

\section{$l_{0}:$ 喽層内における混合距離}

$u_{z}^{\prime}:$ 流れの深さ方向変動成分

の形で表現できると考えられる. 山田・川端(1),7)は浸透 層 (磂層) 内の混合距離として

$$
\begin{aligned}
& l_{0}=k B \\
& B=\frac{2 \lambda^{2}}{3(1-\lambda)} d \\
& k \text { : 定数 } \\
& B \text { ：浸透層内空隙スケール } \\
& \lambda \text { : 浸透層内空隙率 } \\
& d: \text { 粒径 }
\end{aligned}
$$

の形を考え，浸透層内の流速分布について理論的考察を 加え， $k$ の值はおおむね 1 であることを実験的に示した。 上式に従って本実験水路における磁層内混合距離を計算 し，さらに乱れの等方性を磷層境界面において仮定し， $\sqrt{\overline{u_{z}^{\prime 2}}}=\sqrt{u^{\prime 2}}$

$$
u^{\prime}: \text { 流れの主流方向変動成分 }
$$




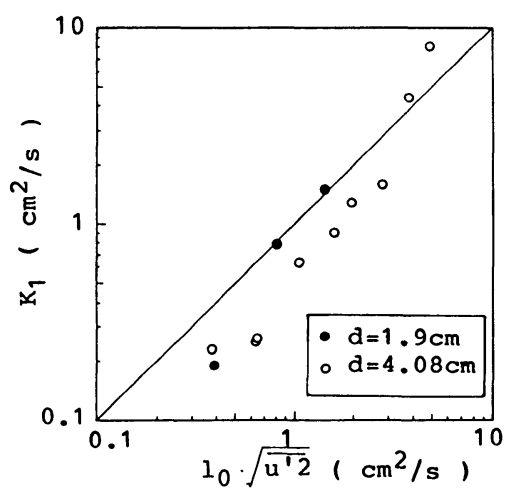

Fig. 14 Relationship between diffusion coefficient near porous boundary $\left(K_{1}\right)$ and $l_{0} \cdot \sqrt{u^{\prime 2}}$.

$l_{0}$ : mixing length in porous media

$\sqrt{u^{\prime 2}}$ : intensity of turbulence at porous boundary

を考慮して, 碩層境界面における乱れ強度と混合距離と の積と境界面付近における深さ方向拡散係数 $K_{1}$ をプ ロットしたものが, Fig. 14 である.この図よりプロッ トはおおむね

$$
K_{1}=l_{0} \cdot \sqrt{u^{\prime 2}}
$$

の線上付近に集まっており，本実験条件の範囲内におい ては碩層表面付近の深さ方向拡散係数が式（15）で表現 し得ることが実験的に示された。

磁層境界面における物質輸送のメカニズムを現象的に 考えると境界付近の比較的大きな渦（粒径程度のスケー ル）が深さ方向への物質輸送を主に担っていると考えら れる. 従来 ${ }^{8), 91}$ ，四型流路における水質交換モデル等で みられるように，フィック型の拡散方程式で説明せずに 水質交換速度 $q$ （速度の次元をもつ）を導入し物質輸送 フラックスを

$$
\begin{aligned}
& F=q \cdot\left(c_{A}-c_{d}\right) \cdot \\
& F \text { : フラックス } \\
& c_{A} \text { : 主流部濃度 } \\
& c_{d} \text { : 死水部（踩層内）濃度 }
\end{aligned}
$$

の形で表現する方法がとられてきているが，本論文で示 されたように，フィック型の拡散モデルを導入し，大き な渦による移流をも含めた形での包括的な見掛けの拡散 係数を考えても十分に輸送現象を記述し得ることがわ かった。 また，拡散係数と乱れ強度の関係より，さらに 一般的な水理学的指標を用いて碩層における物質輸送の 機構を記述する可能性が開けたと考える.

( 2 )

\section{群首における拡散係数の鉛直分布と水兵浄化機 構}

磁層内に付着した生物膜による河川の自净作用を解明 するには喽層内の深さ方向の物質輸送機構と反応を担う 生物の反応の大きさを知る必要がある.

碩層内に一様に生物膜が付着し，かつ深さ方向の拡散
係数が一様で深さ方向に分布がないと仮定すると碟層内

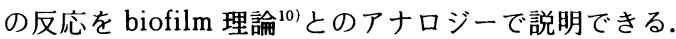
考える生物反応が濃度に対し一次反応で表わせるとする と，定常状態を考えて，碩層内での濃度分布に関し，

$$
\begin{aligned}
& K \frac{d^{2} S(z)}{d z^{2}}=k S(z) \\
& S(z) \text { : 消費される物質の濃度（基質濃度） } \\
& z \text { : 深さ } \\
& K \text { : 深さ方向拡散係数 } \\
& k: \text { 一次反応速度定数 }
\end{aligned}
$$

が成立する. 砅層表面 $(z=0)$ における基質濃度を $S_{0}$, 砅層の厚さを $L$ とすると $z=\xi L, S=S^{*} S_{0}$ で式 (17) を無次元化し,

$$
\begin{aligned}
& \frac{d^{2} S^{*}(\xi)}{d \xi^{2}}=\frac{k L^{2}}{K} S^{*}(\xi)=\alpha^{2} S^{*}(\xi) \\
& \alpha=\sqrt{\frac{k L^{2}}{K}} \ldots \ldots \ldots \ldots \ldots \ldots \ldots \ldots \ldots \ldots \ldots \ldots \ldots
\end{aligned}
$$

となる.この $\alpha$ は碟層内の基質濃度分布を決定づける 無次元パラメーターである (biofilm 理論における“the biofilm constant" ${ }^{10)}$ ). 同パラメーターは拡散係数 $K$ と 一次反応速度定数 $k$ との比の形をしており, この両者 の大小関係によって䃇層内の生物膜反応の機構が左右さ れる.たとえば $\alpha$ が大きい(拡散に比して反応が大きい) と砅層表面付近で基質が消費されてしまい，深部まで十 分に届かず, 逆に $\alpha$ が小さい(拡散に比して反応が小 さい）と䃯層深部まで基質が届くことになる.

ところが本研究の結果から明らかになったように砂層 内で拡散係数は分布している (Fig. 10, Fig.11 参照). さらに䃯層内における水理学的諸条件（流速, 乱れ等) の分布や基質濃度分布によって付着生物量も一様ではな く深さ方向に分布している ${ }^{3)}$ と考えられ, 一次反応速度 定数 $k$ も䃯層内で一様とはいえない. 䃯層内の反応機 構は以上のような複雑な要素が加わるため, 実際は先に 示したような biofilm 理論とのアナロジーで単純化する ことはできず, 式（17）の代わりにより一般的な式

$$
\frac{d}{d z}\left\{K(z) \frac{d S(z)}{d z}\right\}=k(z) S(z)
$$

に従って解析しなければならない．拡散係数 $K(z)$ の分 布については本研究の水理学的条件の範囲内では解明さ れたが，生物反応に関する速度定数 $k(z)$ の分布につい てはまだ明らかになっておらず，今後の研究を待たなけ ればならない. さらに考える基質が 2 種類以上ある場合 は機構がますます複雑化し，たとえば窒素分布と溶存酸 素濃度分布を考えて，碩層内で硝化，脱窒の同時進行の 可能性を議論するには新たな解析が必要となる。 


\section{5. 結}

\section{論}

以上の実験の範册内の結論をまとめて箇条書きで記 す.

（1）碩を有する水路床上の流れは平板上の流れと大 きく異なって䃯層境界面において発生する非常に大きな 乱れ強度にその特徴がある．碩層境界面における乱れ強 度の大きさは, 粒径 $1.9 \mathrm{~cm} \sim 4.08 \mathrm{~cm}$, 表面流 3.9 $\mathrm{cm} / \mathrm{s} \sim 42.8 \mathrm{~cm} / \mathrm{s}$ の範囲内では表面流平均流速の $20 \%$ 程度である.

（2）䃯層内の深さ方向拡散係数は表面流平均流速の 增大に伴って値が大きくなる. またその深さ方向の分布 としては, 磷層境界付近から深くなるにつれて直線的に 值が減少し, 境界から 3 4 層目においては表面流平均 流速の 10 ～ $50 \%$ 程度の値になる.

（3）碩層境界面付近における深さ方向拡散係数は, 境界面における乱れ強度と碅層の空隙スケールとの積の 形で表現できる.

謝辞：本研究は文部省科学研究費補助金, 鉄鋼業 環境保全技術開発基金の研究助成, および財団法人小川 育英会の研究助成を一部受けたものである。ここに謝意
を表します。

1）建設省京浜工事事務所：野川净化施設の効果, 河川, 457, pp. 20 28, 1984.

2）津久井・菊地・紺野：清流の復活に関する研究（その 1), 東京都環境科学研究所年報 1986, pp. 114 119.

3）長岡・大垣：喽で構成された河床における生物学的自浄 作用，水質污濁研究，Vol.9, pp. 520 527，1986.

4）長岡・中村・大垣：碩で構成された水路床における硝化 脱窒機構, 土木学会第 42 回年次講演会, pp. 924 925.

5）吉村元男 - 芝原幸夫：水辺の計画と設計, 鹿島出版会, 1985.

6）山田 正・川端規之：浸透層上の流れの抵抗則に関する 理論的研究, 土木学会論文報告集, 325, pp. $69 \sim 80,1982$.

7）山田 正・川端規之：浸透層上の流れの抵抗則に関する 実験的研究，土木学会論文報告集, 325, pp. 81 91，1982.

8）松岡 譲・河川くぼみ部の水質交換特性について, 土木 学会論文報告集, 280, pp. 39 50, 1978.

9）八木俊策：凹部界面における渦の発生・成長と水質交換, 第 27 回水理講演会論文集, pp. 813 819，1983.

10) Harremoës, P. : Biofilm Kinetics In "Water Pollution Microbiology” (Edited by Michell, R. ), Vol. 2, Wiley, New York, pp. 82 109, 1978.

(1987.5.22 - 受付 